\title{
Survei Asupan Asam Folat dan Seng pada Ibu Hamil di Jawa Barat
}

\author{
Sri Rahayu ${ }^{1}$, Lani Gumilang ${ }^{2}$, Sri Astuti ${ }^{3}$, Sefita Aryuti Nirmala ${ }^{4}$, \\ R. Tina Dewi Judistiani ${ }^{5}$ \\ Fakultas Kedokteran, Universitas Padjadjaran 1,2,3,4,5 \\ srirahayuputri5@gmail.com ${ }^{1}$
}

\section{ABSTRAK}

Diajukan 1 Mei 2019 Diperbaiki 29 Mei 2019 Diterima 19 Agustus 2019

\begin{abstract}
Latar Belakang: Kurangnya asupan asam folat dan
berdomisili di Kota Sukabumi, Kabupaten Cirebon, seng yang berdampak pada ibu maupun janin, untuk penelitian mengenai asupan asam folat dan seng di Jawa Barat masih terkategorikan cukup rendah.

Tujuan: Tujuan penelitian ini untuk mengetahui asupan dan rerata asam folat dan seng pada ibu hamil di Jawa Barat.

Metode: Metode penelitian ini adalah deskriptif dengan desain penelitian cross sectional, dan sampel dipilih dengan menggunakan metode total sampling dari penelitian Academic Leadership Grant (ALG). Berdasarkan penelitian tersebut, jumlah ibu hamil Kota Bandung, dan Kota Cimahi yang diambil pada periode Juli 2016 - Februari 2017. Sumber data yaitu data sekunder dari food diary. Analisis data univariat. Hasil: Sebagian besar responden yang asupan asam folatnya tidak terpenuhi yaitu sebesar $97,2 \%$ dan asupan sengnya tidak terpenuhi yaitu sebesar $96 \%$ dengan rerata asupan asam folat $163 \mathrm{mg} /$ hari dan rerata asupan seng $5,1 \mathrm{mg} /$ hari.

Kesimpulan: Sebagian besar responden termasuk dalam kategori asupan asam folat dan seng yang tidak terpenuhi dengan rerata dibawah anjuran Angka Kebutuhan Gizi (AKG) ibu hamil.
\end{abstract}

trimester 1 sebanyak 176 responden yang

Kata Kunci: asam folat; ibu hamil; seng; survei

\section{ABSTRACT}

Background: The lack of folic acid and zinc intake has considerable impact on both mother and fetus, and based on this research, the intake of folic acid and zinc among pregnant women in West Java is still quite low.

Objective: The purpose of this research was to know the intake and average of folic acid and zinc among pregnant women in West Java.

Methods: The method of this research was descriptive using cross sectional research design, and the sample was selected by using total sampling method from research of Academic Leadership Grant (ALG) on all first trimester pregnant women as many as 176 respondents who lived in the city of Sukabumi, Cirebon, Bandung and Cimahi recruited in the period of July 2016 - February 2017. Data source was the secondary data from food diary. The analysis used univariate data.

Results: Most of the respondents with the folic acid intake not fulfilled were $97,2 \%$ and most of them with the zinc intake not fulfilled were $96 \%$, with the average of folic acid intake $163 \mu \mathrm{g} /$ day and the average of zinc intake 5,1 mg/day.

Conclusion: Most of the respondents are categorized in the not fulfilled folic acid and zinc intake with the average under the Recommended Dietary Allowances (RDA) for pregnantwomen.

Keywords: folic acid; pregnant women; zinc; survey 


\section{PENDAHULUAN}

Tubuh tidak hanya membutuhkan makronutrien, tetapi juga mikronutrien (Wahyuni et al., 2013). Mikronutrien dibutuhkan dalam jumlah sedikit tetapi temasuk komponen penting yang harus dipenuhi karena memberikan dampak yang besar bagi kesehatan tubuh (Unicef, 2015).

Menurut Centers for Disease Control and Prevention (CDC), pada tahun 2015, sekitar 2 miliar orang di dunia mengalami kekurangan mikronutrien. Berdasarkan Food and Nutrition Technical Assistance III Project (FANTA), negara di Asia termasuk ke dalam daftar negara yang mengalami kejadian malnutrisi cukup tinggi (kekurangan energi kronis dan kekurangan mikronutrien) yaitu sekitar 10-40\% (FANTA, 2014).

Penelitian sebelumnya memperoleh hasil bahwa ibu hamil rentan mengalami kekurangan mikronutrien karena saat kehamilan terjadi pertumbuhan janin yang cepat, diferensiasi organ, dan pembelahan sel yang cepat (Sengpiel et al., 2013, Lassi et al., 2013, Gernand et al., 2016).

Mikronutrien yang dibutuhkan saat kehamilan diantaranya adalah asam folat dan seng yang berfungsi untuk perkembangan sistem saraf (Spann et al., 2015). Penelitian yang dilakukan di Asia Selatan menunjukkan bahwa ibu hamil yang mengalami kekurangan asam folat sekitar $12 \%$ - 26\% dan kekurangan seng sekitar 15-74\% (Gernand et al., 2016).

Dampak dari kekurangan asam folat pada saat hamil dapat menyebabkan anemia, abortus, Bayi Berat Lahir Rendah (BBLR), anemia pada bayi, prematur, kematian perinatal, dan Neural Tube Defect (NTD) (Lassi et al., 2013). Angka kejadian NTD yaitu 1 - 10 per 1.000 kelahiran hidup (Gernand et al., 2016). Berdasarkan penelitian, menunjukkan 90\% NTD dapat dicegah dengan asupan asam folat yang baik (Czeizel et al., 2013).

Dampak kekurangan seng pada ibu hamil juga dapat menyebabkan abortus, kelahiran prematur, kematian janin dalam kandungan, dan NTD (Wang et al., 2015).
Berdasarkan penelitian, asupan seng yang baik dapat menurunkan risiko kelahiran prematur sebesar 14\% (Lamberti et al., 2016).

Penelitian di Indonesia dan daerah Jawa Barat mengenai asupan asam folat dan seng pada ibu hamil masih cukup rendah, sedangkan dampak yang ditimbulkan jika mengalami kekurangan asam folat dan seng cukup besar. Oleh karena itu, penelitian ini bertujuan untuk mengetahui asupan dan rerata asam folat dan seng pada ibu hamil di Jawa Barat.

\section{METODE}

Metode yang digunakan adalah deskriptif dengan desain penelitian cross sectional. Sumber data yaitu data sekunder dari food diary. Penelitian ini merupakan bagian dari penelitian Academic Leadership Grant (ALG) yang dipimpin oleh Prof. Dr. Budi Setiabudiawan, dr., Sp.A(K), M.Kes. dengan judul Peran Vitamin D dalam upaya menurunkan AKI dan AKB di Jawa Barat. Sampel dari penelitian tersebut menggunakan metode total sampling yakni sejumlah ibu hamil trimester 1 sebanyak 176 responden, dengan waktu pengambilan data yaitu periode Juli 2016-Februari 2017.

Penelitian ini merupakan penelitian komunitas dengan menggunakan 4 wilayah di Jawa Barat dengan tujuan pemerataan geografis, sehingga dipilih Kota Madya Sukabumi sebagai batas barat dan selatan yang mewakili wilayah pantai, Kabupaten Cirebon sebagai batas timur dan utara yang mewakili wilayah pegunungan, Kota Madya Bandung, dan Kota Cimahi sebagai bagian tengah dari Jawa Barat yang mewakili wilayah kota.

Dalam penelitian ini, kriteria inklusi mengikuti kohort penelitian vitamin $\mathrm{D}$, yaitu ibu hamil trimester 1 dan data lengkap food diary. Variabel dalam penelitian ini adalah asupan asam folat dan seng pada ibu hamil. Instrumen yang digunakan dalam penelitian ini adalah lembar food diary.

Pengolahan data dilakukan dengan mengubah asupan nutrisi dari Ukuran Rumah 
Tangga (URT) ke ukuran berat (gram) menggunakan buku panduan gizi Departemen Kesehatan (Depkes)(RI, 2014). Asupan makanan kemudian dihitung menggunakan software yang bernama nutrisurvey untuk mendapatkan angka asupan asam folat dan seng (Erhardt, 2007). Asupan asam folat dan sengnya diubah ke data ordinal dalam program SPSS versi 20. Analisis data menggunakan univariat (Dahlan, 2012). Protokol studi ini telah mendapatkan persetujuan etik dari komisi etik penelitian kesehatan (No etik 742/UN6.C1.3.2/KEPK/PN/2015).

\section{HASIL DAN PEMBAHASAN}

Tabel 1. Karakteristik Responden Asupan Asam Folat pada Ibu Hamil di Jawa Barat

\begin{tabular}{lccccc}
\hline \multirow{3}{*}{ Karakteristik } & Kategori & \multicolumn{4}{c}{ Asam Folat } \\
\cline { 3 - 6 } & & Terpenuhi & \multicolumn{2}{c}{ Tidak } \\
& & ferpenuhi \\
\cline { 3 - 6 } Usia & $<20$ tahun & 0 & 0 & 17 & 9,7 \\
& $20-35$ & 5 & 2,8 & 131 & 74,4 \\
& tahun & 0 & 0 & 23 & 13,1 \\
& $>35$ tahun & & & & \\
\hline Paritas & Nulipara & 2 & 1,1 & 57 & 32,4 \\
& Primipara & 1 & 0,6 & 67 & 38,1 \\
& Multipara & 2 & 1,1 & 46 & 26,1 \\
& Grande & 0 & 0 & 1 & 0,6 \\
& Multipara & & & & \\
\hline Pekerjaan & Petani & 0 & 0 & 0 & 0 \\
& Guru/PNS & 0 & 0 & 8 & 4,5 \\
& IRT & 4 & 2,3 & 141 & 80,1 \\
& Pegawai & 0 & 0 & 8 & 4,5 \\
& Swasta & & & & \\
& Wiraswasta & 1 & 0,6 & 14 & 8,0 \\
\hline Pendidikan & SD & 2 & 1,1 & 61 & 34,6 \\
& SMP & 1 & 0,6 & 57 & 32,4 \\
& SMA & 1 & 0,6 & 35 & 19,9 \\
& PT & 1 & 0,6 & 18 & 10,2 \\
\hline
\end{tabular}

Tabel 2. Karakteristik Responden Asupan Seng pada Ibu Hamil di Jawa Barat

\begin{tabular}{|c|c|c|c|c|c|}
\hline \multirow{3}{*}{ Karakteristik } & \multirow{3}{*}{ Kategori } & \multicolumn{4}{|c|}{ Seng } \\
\hline & & \multicolumn{2}{|c|}{ Terpenuhi } & \multicolumn{2}{|c|}{$\begin{array}{c}\text { Tidak } \\
\text { Terpenuhi }\end{array}$} \\
\hline & & f & $\%$ & f & $\%$ \\
\hline \multirow[t]{3}{*}{ Usia } & $<20$ tahun & 0 & 0 & 17 & 9,7 \\
\hline & $\begin{array}{l}20-35 \\
\text { tahun }\end{array}$ & 7 & 4 & 129 & 73,3 \\
\hline & $>35$ tahun & 0 & 0 & 23 & 13 \\
\hline \multirow[t]{4}{*}{ Paritas } & Nulipara & 4 & 2,3 & 55 & 31,2 \\
\hline & Primipara & 1 & 0,6 & 67 & 38,1 \\
\hline & Multipara & 2 & 1,1 & 46 & 26,1 \\
\hline & $\begin{array}{l}\text { Grande } \\
\text { Multipara }\end{array}$ & 0 & 0 & 1 & 0,6 \\
\hline \multirow[t]{5}{*}{ Pekerjaan } & Petani & 0 & 0 & 0 & 0 \\
\hline & Guru/PNS & 0 & 0 & 8 & 4,6 \\
\hline & IRT & 5 & 2,8 & 140 & 79,5 \\
\hline & $\begin{array}{c}\text { Pegawai } \\
\text { Swasta }\end{array}$ & 0 & 0 & 8 & 4,6 \\
\hline & Wiraswasta & 2 & 1,1 & 13 & 7,4 \\
\hline \multirow[t]{4}{*}{ Pendidikan } & SD & 2 & 1,1 & 61 & 34,6 \\
\hline & SMP & 4 & 2,3 & 54 & 30,7 \\
\hline & SMA & 1 & 0,6 & 35 & 19,9 \\
\hline & PT & 0 & 0 & 19 & 10,8 \\
\hline
\end{tabular}

Tabel 1 dan 2 menunjukkan bahwa dari segi usia sebagian besar responden berada pada usia reproduksi sehat, ibu sudah pernah melahirkan 1 kali, pekerjaan ibu sebagai Ibu Rumah Tangga (IRT), dan pendidikan Sekolah Dasar (SD).

Tabel 3. Rerata Asupan Asam Folat dan Seng pada Ibu Hamil di Jawa Barat

\begin{tabular}{lc}
\hline \multicolumn{1}{c}{ Jenis Asupan } & Rerata \\
\hline Asam Folat & $163 \mu \mathrm{g} /$ hari \\
Seng & $5,1 \mathrm{mg} /$ hari \\
\hline
\end{tabular}

Tabel 4. Asupan Asam Folat pada Ibu Hamil di Jawa Barat

\begin{tabular}{ccc}
\hline \multicolumn{1}{c}{ Asupan Asam Folat } & F & \% \\
\hline Tidak terpenuhi $(<600 \mu \mathrm{g})$ & 171 & 97,2 \\
Terpenuhi $(\geq 600 \mu \mathrm{g})$ & 5 & 2,8 \\
\hline \multicolumn{1}{c}{ Jumlah } & $\mathbf{1 7 6}$ & $\mathbf{1 0 0}$ \\
\hline
\end{tabular}

Tabel 4 menunjukkan bahwa 97,2\% responden asupan asam folatnya tidak terpenuhi dan hanya sebagian kecil responden yang asupan asam folatnya terpenuhi yaitu sebesar $2,8 \%$.

Tabel 5. Asupan Seng pada Ibu Hamil di Jawa Barat

\begin{tabular}{lcc}
\hline \multicolumn{1}{c}{ Asupan Seng } & F & \% \\
\hline Tidak terpenuhi $(<12 \mathrm{mg})$ & 169 & 96 \\
Terpenuhi $(\geq 12 \mathrm{mg})$ & 7 & 4 \\
\hline \multicolumn{1}{c}{ Jumlah } & $\mathbf{1 7 6}$ & $\mathbf{1 0 0}$ \\
\hline
\end{tabular}

Tabel 5 terlihat bahwa 96\% responden asupan sengnya tidak terpenuhi dan hanya sebagian kecil responden yang asupan sengnya terpenuhi yaitu sebesar 4\%.

Menurut Permenkes tahun 2013 mengenai AKG ibu hamil, kebutuhan asam folat pada ibu hamil trimester 1 yaitu 600 $\mu \mathrm{g} /$ hari (RI, 2013). Berdasarkan hasil penelitian yang tertera pada tabel 3, rerata asupan asam folat pada 176 responden yaitu sebesar 163 $\mu \mathrm{g} /$ hari.

Apabila dibandingkan dengan penelitian yang dilakukan pada 59 ibu hamil di Padang yang rerata asupan asam folatnya sebesar 341,95 $\mu \mathrm{g} /$ hari (Septiyeni et al., 2016), maka rerata asupan asam folat pada penelitian ini lebih rendah. Namun apabila dibandingkan dengan penelitian di Indonesia lainnya, yang dilakukan pada 606 ibu hamil dengan rerata asupan asam folat sebesar 98,7 $\mu \mathrm{g} /$ hari 
(Ningrum, 2016), maka rerata asupan asam folat pada penelitian ini lebih tinggi.

Data pada tabel 4 menunjukkan bahwa sebagian besar responden termasuk dalam kategori asupan asam folat yang kurang yaitu sebesar $97,2 \%$. Pada penelitian yang dilakukan di Kabupaten Gowa tahun 2013 pada 66 ibu hamil, didapatkan bahwa 100\% responden asupan asam folatnya masih dalam kategori kurang (Wahyuni et al., 2013). Apabila dibandingkan dengan penelitian tersebut, maka asupan asam folat pada penelitian ini lebih tinggi. Namun berdasarkan penelitian lainnya pada $606 \mathrm{ibu}$ hamil, angka kekurangan asam folatnya sebesar 88,3\% (Ningrum, 2016), maka hasil penelitian ini lebih rendah.

Dibandingkan dengan hasil penelitian yang telah dipaparkan sebelumnya, hasil rerata dan asupan asam folat bervariasi. Hal tersebut disebabkan karena perbedaan teknik pemilihan sampel yang digunakan, instrumen penelitian yang digunakan, wilayah penelitian, dan karakteristik responden seperti usia, paritas, pekerjaan, dan pendidikan (Septiyeni et al., 2016, Wahyuni et al., 2013, Ningrum, 2016).

Selain itu, proses pengolahan makanan juga dapat menyebabkan hilangnya kandungan asam folat (Ningrum, 2016) karena sifat asam folat yang rentan terhadap panas dan mudah larut dalam air sehingga akan hilang jika dimasak atau disimpan terlalu lama (Fraser and Cooper, 2011).

Penelitian ini menghasilkan nilai terendah asupan asam folat sebesar 7,2 $\mu \mathrm{g} /$ hari. Apabila dibandingkan antara asupan asam folat terendah pada responden dengan asupan asam folat yang dianjurkan, maka responden tersebut hanya memenuhi asupan asam folat sebesar 1,2\%. Adapun jenis makanan yang dikonsumsi oleh responden dengan asupan asam folat terendah didominasi dengan mengkonsumsi nasi, bakso, gorengan serta tidak mengkonsumsi sayuran. Kurangnya asupan asam folat saat kehamilan dapat menyebabkan kerusakan pada otak dan batang otak, yaitu spina bifida dan anensefali. Kedua kerusakan batang otak tersebut dapat menyebabkan gangguan pada saraf, sehingga panca indra, kemampuan intelektual, dan kemampuan gerak bayi menjadi terhambat (Sinsin, 2008).

Mayoritas responden penelitian ini yang asupan asam folatnya sesuai dengan anjuran AKG yaitu sebesar 747,3 $\mu \mathrm{g}$ /hari, dominasi makanannya mengandung tinggi asam folat seperti nasi, energen/sereal, ketupat, daging ayam, pisang, dan jus jeruk. Pada responden yang asupan asam folatnya mencapai nilai tertinggi yaitu sebesar 1.814,3 $\mu \mathrm{g} / \mathrm{hari}$, responden memenuhi asupan asam folat $3 \mathrm{kali}$ lipat dari asupan asam folat yang dianjurkan menurut AKG.

Responden dengan asupan asam folat tertinggi terlalu banyak mengkonsumsi makanan yang mengandung asam folat seperti bubur ayam, nasi, energen, sayur bayam, sayur sup, dan pisang.

Dilihat dari variasi makanan responden yang asam folatnya tidak terpenuhi, jenis konsumsi makanan yang mengandung tinggi asam folat yaitu seperti sayur sup, bubur kacang hijau, dan pepaya. Variasi makanan pada responden dengan asupan asam folat terpenuhi, jenis makanan, dan kuantitas makanan yang dikonsumsi mengandung tinggi asam folat seperti nasi, telur, sayur sup, dan sup ayam.

Perbandingan variasi makanan yang dikonsumsi responden dengan asupan asam folat tidak terpenuhi dan terpenuhi, dua responden tersebut sudah mengkonsumsi jenis makanan yang mengandung tinggi asam folat. Akan tetapi, responden dengan asupan asam folat yang tidak terpenuhi, segi kuantitas makanan yang dikonsumsi terlalu sedikit meskipun jenisnya sama, contohnya kedua responden sama-sama mengkonsumsi sayur sup. Responden dengan asupan asam folat tidak terpenuhi hanya mengkonsumsi sayur sup sebanyak 60 gram sekali makan, sedangkan responden dengan asupan asam folat terpenuhi mengkonsumsi sayur sup sebanyak 250 gram atau setara 1 mangkuk kecil sekali makan. 
Menurut Permenkes tahun 2013 mengenai AKG ibu hamil, kebutuhan seng pada ibu hamil trimester 1 yaitu $12 \mathrm{mg} /$ hari. Berdasarkan hasil penelitian pada tabel 3, rerata asupan seng dari 176 responden yaitu sebesar 5,1 mg/hari. Apabila dibandingkan dengan penelitian yang dilakukan pada $59 \mathrm{ibu}$ hamil di Padang, rerata asupan seng sebesar 5,07 mg/hari (Septiyeni et al., 2016), maka rerata asupan seng pada penelitian ini lebih tinggi.

Terlihat pada tabel 5, sebagian besar responden termasuk dalam kategori asupan seng yang tidak terpenuhi yaitu sebesar $96 \%$. Asupan seng yang baik bermanfaat untuk menghindari risiko lahir prematur dan kelahiran bayi dengan BBLR (Anggarani and Subakti, 2013).

Penelitian yang dilakukan di Kabupaten Gowa tahun 2013 pada 66 ibu hamil, didapatkan bahwa 100\% responden asupan sengnya masih dalam kategori kurang (Wahyuni et al., 2013). Apabila dibandingkan dengan penelitian tersebut, maka asupan seng pada penelitian ini lebih tinggi karena terdapat $4 \%$ responden dengan asupan seng yang terpenuhi.

Beberapa penelitian yang telah dikemukakan, menunjukkan hasil rerata dan asupan seng yang bervariasi. Hal tersebut dapat disebabkan karena perbedaan teknik pemilihan sampel yang digunakan, instrumen penelitian yang digunakan, wilayah penelitian, dan karakteristik responden meliputi usia, pekerjaan, dan pendidikan (Wahyuni et al., 2013, Septiyeni et al., 2016).

Penelitian ini menghasilkan nilai terendah asupan seng sebesar 1,0 mg/hari. Apabila asupan seng terendah pada responden dengan asupan seng yang dianjurkan dibandingkan, maka responden tersebut hanya memenuhi asupan seng sebesar $8,3 \%$. Adapun jenis makanan yang dikonsumsi oleh responden didominasi dengan jenis makanan yang banyak mengandung seng, tetapi dilihat dari segi frekuensi makan dan kuantitas makanan yang dikonsumsi hari terlalu sedikit untuk memenuhi kebutuhan nutrisi ibu hamil.
Kurangnya asupan seng saat kehamilan dapat menyebabkan penurunan nafsu makan ibu, gangguan penyembuhan luka, terhambatnya pertumbuhan janin, dan kretinisme pada bayi. Selain itu, dalam penelitian lainnya dinyatakan bahwa kekurangan seng dapat meningkatkan risiko komplikasi maternal seperti, hipertensi, preeklampsia, perdarahan intrapartum, infeksi, persalinan lama, kelahiran prematur, kelainan kongenital, pertumbuhan janin terhambat, dan BBLR (Wibisono and Dewi, 2009, Cunningham et al., 2014, Lamberti et al., 2016, Abass et al., 2014).

Sebagian besar responden yang asupan sengnya sesuai dengan anjuran AKG yaitu sebesar 17,0 mg/hari. Adapun jenis makanan yang dikonsumsi didominasi dengan makanan yang mengandung tinggi seng seperti sayur sup, daging ayam, susu, dan energen/sereal.

Penelitian ini diperoleh nilai tertinggi asupan seng sebesar $47 \mathrm{mg} /$ hari. Adapun jenis makanan yang dikonsumsi responden dilihat dari segi frekuensi makan dan kuantitas makanan yang dikonsumsi sehari-hari, banyak makanan yang mengandung seng.

Variasi makanan pada responden yang asupan sengnya tidak terpenuhi, dari segi jenis makanan yang dikonsumsi sudah baik yaitu responden sudah mengkonsumsi beberapa jenis makanan yang mengandung tinggi seng seperti susu ibu hamil, sayur sup, dan sayur asem, sedangkan variasi makanan pada responden dengan asupan seng terpenuhi, jenis makanan dan kuantitas makanan yang dikosumsi sudah baik, seperti makanan yang mengandung tinggi seng yaitu susu ibu hamil, rendang, dan sayur sup.

Perbandingan variasi makanan yang dikonsumsi responden dengan asupan seng tidak terpenuhi dan terpenuhi, dua responden tersebut sudah mengkonsumsi jenis makanan yang mengandung tinggi seng. Responden dengan asupan seng yang tidak terpenuhi, frekuensi makanan yang dikonsumsi ibu terlalu sedikit, sedangkan untuk responden dengan asupan seng terpenuhi sudah 
mengkonsumsi makanan yang mengandung tinggi seng, baik dari segi kuantitas maupun frekuensi makan.

Penjelasan dari uraian di atas, terdapat beberapa karakteristik responden yang dapat memengaruhi rerata dan asupan asam folat maupun seng diantaranya usia, paritas, pekerjaan, dan pendidikan. Berdasarkan tabel 1 dan 2, terlihat bahwa asupan asam folat dan seng yang terpenuhi terdapat pada rentang usia 20 - 35 tahun yaitu masing-masing sebesar $2,8 \%$ dan $4 \%$, sedangkan pada usia $<20$ tahun dan $>35$ tahun tidak ada responden yang terpenuhi asupan asam folat dan sengnya.

Usia memengaruhi pemahaman dan pola berpikir seseorang. Semakin bertambahnya usia maka semakin berkembang juga pola pikirnya, semakin bertambahnya usia maka semakin banyak juga pengetahuan dan pengalaman yang dimiliki. Dalam sebuah penelitian menyebutkan semakin bertambahnya usia maka semakin bertambah juga kebutuhan gizi dan semakin baik juga status gizi yang dimiliki (Wibowo, 2014).

Ibu yang hamil pada usia $<20$ tahun belum siap secara psikis untuk kehamilan sehingga tidak memerhatikan asupan nutrisinya, kemudian akan berdampak kepada asupan zat gizi janin yang tidak terpenuhi dengan baik. Selain itu, asupan nutrisi saat kehamilan bukan hanya dibutuhkan untuk pertumbuhan janin saja, tetapi dibutuhkan juga untuk pertumbuhan fisik ibu karena masih dalam tahap pertumbuhan (Ningrum, 2016, Triatmaja, 2017).

Ibu hamil pada usia $>35$ tahun mengalami penurunan fungsi organ reproduksi dan organ yang lain seperti organ pencernaan, sehingga organ pencernaan tidak dapat menyerap nutrisi dengan baik dan menyebabkan tidak terpenuhinya asupan nutrisi ibu (Purbadewi dan Ulvie, 2013).

Dilihat dari tabel 1 dan 2, asupan asam folat dan seng yang terpenuhi kebanyakan pada ibu yang belum pernah melahirkan atau nulipara, yaitu masing-masing sebesar 1,1\% dan $2,3 \%$. Hal ini dikarenakan ibu yang hamil untuk pertama kali akan lebih banyak mencari informasi mengenai kehamilannya dan mengenai asupan gizi untuk kehamilannya (). Semakin banyaknya paritas maka semakin menurunnya status gizi ibu (Afrilia, 2017).

Merujuk pada literatur keluarga yang memiliki jumlah anak banyak, jumlah anak yang banyak diikuti dengan distribusi dan jumlah makanan yang tidak merata maka dapat menyebabkan tidak terpenuhi kebutuhan nutrisi ibu (Istiany and Rusilanti, 2014). Berdasarkan tabel 1 dan 2, asupan asam folat dan seng yang tidak terpenuhi banyak pada ibu yang tidak bekerja atau Ibu Rumah Tangga (IRT), yaitu masing-masing sebesar $80,1 \%$ dan $79,5 \%$. Pekerjaan berhubungan dengan pendapatan dalam keluarga.

Hasil penelitian menunjukkan bahwa seseorang yang mengalami kekurangan gizi lebih banyak terjadi pada tingkat ekonomi rendah. Menurut hasil penelitian (), keluarga yang memiliki status ekonomi golongan menengah dan bawah berisiko mengalami kekurangan nutrisi, karena rendahnya daya beli terhadap jenis makanan menyebaban ibu tidak dapat memenuhi kebutuhan nutrisinya dengan baik (Triatmaja, 2017).

Tabel 1 dan 2, diketahui bahwa asupan asam folat dan seng yang tidak terpenuhi banyak pada ibu yang berpendidikan SD, yaitu masing-masing sebesar $34,6 \%$. Berdasarkan penelitian, tingkat pendidikan turut menentukan seseorang dalam menyerap dan memahami pengetahuan yang diperoleh, dimana semakin tinggi tingkat pendidikan seseorang maka semakin banyak juga pengetahuan yang dimiliknya. Dalam hal tersebut, ia juga akan semakin mudah m e n g e r t i, m e m a ha m i, d a n mengimplementasikan informasi yang didapatkan, khususnya informasi mengenai kesehatan dan gizi (Putri et al., 2015, Kartikasari, 2014).

Hasil penelitian ini dapat memberikan informasi bahwa masih banyaknya ibu hamil yang kategori asupan asam folat dan sengnya tidak terpenuhi karena berada dibawah rerata 
anjuran AKG ibu hamil. Hal tersebut dapat menjadi masukan bagi dinas kesehatan dan petugas kesehatan untuk lebih banyak melakukan penyuluhan atau pemberian informasi terkait gizi yang dapat dilakukan sebelum dan selama kehamilan, pemberian informasi bukan hanya mengenai makronutrien tetapi juga mikronutrien, sehingga para ibu hamil dapat memenuhi kebutuhan asam folat dan seng dengan baik.

Penelitian ini terdapat beberapa kelebihan diantaranya adalah penggunaan m e to d e food records. Metode tersebut mengharuskan responden untuk mengisi lembar food diary setiap mengkonsumsi makanan dan minuman. Responden mendeskripsikan secara jelas mulai dari nama masakan, bahan masakan, metode memasak, dan bumbu masakan yang diukur dengan menggunakan Ukuran Rumah Tangga (URT) (Susetyowati, 2013).

Food diary tersebut diisi selama 3 hari untuk melihat rerata asupan, sehingga dapat menggambarkan asupan makanan responden. Pada penelitian ini juga terdapat kelemahan yaitu dalam buku panduan gizi Departemen Kesehatan (Depkes) dan aplikasi nutrisurvey terdapat beberapa bahan makanan yang tidak ada, sehingga ada kemungkinan overestimate dan underestimate.

\section{KESIMPULAN DAN SARAN}

Dapat disimpulkan bahwa sebagian besar responden termasuk dalam kategori asupan asam folat dan seng yang tidak terpenuhi karena nilai rerata asupannya berada dibawah anjuran AKG ibu hamil. Diharapkan setelah penelitian ini, terdapat penelitian yang membahas hubungan faktor-faktor yang memengaruhi asupan nutrisi dengan asupan asam folat dan seng pada ibu hamil, sehingga dapat melakukan intervensi yang sesuai dengan faktor penyebabnya.

\section{DAFTAR PUSTAKA}

Abass, R. M., Hamdan, H. Z., Elhassan, E. M., Hamdan, S. Z., Ali, N. I. \& Adam, I. (2014).
Zinc and copper levels in low birth weight deliveries in Medani Hospital, Sudan. BMC Research Notes. Diakses dari https://doi.org/10.1186/1756-0500-7-386

Afrilia, E. M. (2017). Hubungan Karakteristik Ibu dengan Pengetahuan Tentang Gizi Seimbang Bagi Ibu Hamil di Puskesmas Kecamatan Palmerah Tahun 2013. Indonesian Midwifery Journal. 1(1): 45-53

Anggarani, D. R. \& Subakti, Y. (2013). Kupas tuntas seputar kehamilan. Jakarta Selatan: PT AgroMedia Pustaka.

Cunningham, Leveno, Bloom, Hauth, Rouse \& Spong. (2014). Obstetri Williams. Jakarta: EGC.

Czeizel, A. E., Dudás, I., Vereczkey, A. \& Bánhidy, F. (2013). Folate deficiency and folic acid supplementation: The prevention of Neural-Tube Defects and Congenital Heart Defects. Nutrients. 5(11): 4760-4775.

Dahlan, M. S. (2012). Langkah-langkah membuat proposal penelitian bidang kedokteran dan kesehatan. Jakarta: Sagung Seto.

Erhardt, J. (2007). Nutrisurvey for Windows. University of Indonesia. Tersedia di www.nutrisurvey.de.

FANTA. (2014). Overview of the nutrition situation in seven countries in Southeast Asia. Tersedia di from: www.fantaproject.org. Diakses tanggal 09 Februari 2017.

Fraser, D. M. \& Cooper, M. A. (2011). Buku Ajar Bidan. Jakarta: EGC.

Gernand, A. D., Schulze, K. J., Stewart, C. P., Jr, K. P. W. \& Christian, P. (2016). Micronutrient deficiencies in pregnancy worldwide: health effects and prevention. Nature Reviews Endocrinology. 12(5): 274-289.

Istiany, A. \& Rusilanti (2014). Gizi terapan. PT Remaja Rosdakarya.

Kartikasari, W. R. (2014). Analisis Kebiasaan Makan Masyarakat di Sekitar Waduk Cirata, Kecamatan Ciranjang, Kabupaten Cianjur. Skripsi. Institut Pertanian Bogor. 
Lamberti, L. M., Walker, C. L. F. \& Black, R. E. (2016). Zinc deficiency in childhood and pregnancy: evidence for intervention effects and program responses. Karger Journal/Publisher, 55:125-133.

Lassi, Z. S., Salam, R. A., Haider, B. A. \& Bhutta, Z. A. (2013). Folic acid supplementation during pregnancy for maternal health and pregnancy outcomes. Cochrane Database of Systematic Reviews 2013. 2-3.

Ningrum, E. P. A. (2016). Analisis Asupan Asam Folat, Vitamin B12 Dan Vitamin C Pada Ibu Hamil Di Indonesia Berdasarkan Studi Diet Total. Skripsi. Institut Pertanian Bogor.

Purbadewi, L. \& Ulvie, Y. N. S. (2013). Hubungan Tingkat Pengetahuan Tentang Anemia dengan Kejadian Anemia Pada Ibu Hamil. Jurnal Gizi Universitas Muhammadiyah Semarang. 2(1):31-38.

Putri, R. F., Sulastri, D. \& Lestari, Y. (2015). Faktor-faktor yang berhubungan dengan status gizi anak balita di wilayah kerja Puskesmas Nanggalo Padang. Jurnal Andalas. 4(1): 260.

RI, K. K. (2014). Buku Foto Makanan Survei Konsumsi Makanan Individu. Jakarta.

RI, M. K. (2013). Angka Kecukupan Gizi yang dianjurkan bagi bangsa Indonesia. Available from: gizi.depkes.go.id. Diakses tanggal 19 Januari 2017.

Sengpiel, V., Bacelis, J., Myhre, R., Myking, S., Pay, A. D., Haugen, M., Brantsæter, A.L., Meltzer, H. M., Nilsen, R. M., Magnus, P., Vollset, S. E., Nilsson, S. \& Jacobsson, B. (2013). Folic acid supplementation, dietary folate intake during pregnancy and risk for spontaneous preterm delivery: a prospective observational cohort study. BMC Pregnancy and Childbirth. 13(1): 260
Septiyeni, W., Lipoeto, N. I. \& Serudji, J. (2016). Hubungan asupan asam folat, zink, dan vitamin A ibu hamil trimester III terhadap Berat Badan Lahir di Kabupaten Padang Pariaman. Jurnal Kesehatan Andalas. 5(1): 125-127.

Sinsin, I. (2008). Masa kehamilan dan persalinan. Jakarta: PT Elex Media Komputindo.

Spann, M. N., Smerling, J., Gustafssona, H., Foss, S., Altemus, M. \& Monk, C. (2015). Deficient maternal zinc intake - but not folate-is associated with lower fetal heart rate variability. Early Human Development.

Susetyowati (2013). Penilaian status gizi. Yogyakarta.

Triatmaja, N. T. (2017). Faktor-faktor yang berhubungan dengan status Kurang Energi Kronis (KEK) ibu hamil di Kabupaten Kediri. Jurnal Wiyata. 4.

Unicef. (2015). Micronutrients. Available from: www.unicef.org. Diakses tanggal 25 Januari 2017.

Wahyuni, S., Indriasari, R. \& Salam, A. (2013). Pola konsumsi buah dan sayur serta asupan zat gizi mikro dan serat pada ibu hamil di Kabupaten Gowa 2013. 2.

Wang, H., Hu, Y.-F., Hao, J.-H., Chen, Y.-H., Su, P.-Y., Wang, Y., Yu, Z., Fu, L., Xu, Y.-Y., Zhang, C., Tao, F.-B. \& Xu, D.-X. (2015). Maternal zinc deficiency during pregnancy elevates the risks of fetal growth restriction: a population-based birth cohort study. 1.

Wibisono, H. \& Dewi, A. B. F. K. (2009). Solusi sehat seputar kehamilan. Jakarta Selatan: PT AgroMedika Pustaka.

Wibowo, M. E. (2014). Hubungan karakteristik keluarga, pengetahuan dan sikap gizi, serta PHBS dengan status gizi ibu di daerah kumuh Jakarta Selatan. Skripsi. Institut Pertanian Bogor. 